\title{
A. A. KA3АКOB \\ РОЖАНИЧНЫЕ ТРАПЕЗЫ В КОНТЕКСТЕ ДРЕВНЕРУССКОГО ДВОЕВЕРИЯ: НЕКОТОРЫЕ НАБЛЮДЕНИЯ
}

Отношение христианской цуеркви к деторождению, роженицам и повивальным бабкам оставалось довольно противоречивым во все времена. B cтатье рассматривается вопрос о сущности рожаничных трапез, упоминаемых в древнерусских сочинениях против язычества. Наблюдения автора приводят к выводу, что анализируемылй феномен был связан с язычеством весьма опосредованно, а реконструкция его эволюции позволяет хотя бы отчасти проследить процесс христианизации Руси на уровне быта.

Ключевые слова: восточнославянское язычество, двоеверие, род и рожаниць, христианизация Руси, церковная дисцииплина.

Рожаничные трапезы - безусловно, интересное, хотя и довольно загадочное явление древнерусской религиозной жизни. Свидетельства источников относительно рожаничных трапез весьма специфичны, ибо восходят главным образом к средневековым книжникам, видевшим в этом обычае образчик языческого нечестия, достойный самого жесткого порицания. Такого рода отрицательный интерес имеет свои издержки: рассказывая о рожаничных трапезах, обличители тем не менее не дают четкого представления, что именно скрывалось за этим понятием, на основании каких критериев оно было отнесено к языческим пережиткам. Древнерусское толковое «Слово Исайи пророка» сообщает лишь, что некоторые из современников автора поклоняются «роду и роженицам, кумиром суетным». «Вы же работающе бесом, - утверждает книжник, - и служаще идолом, и ставяще трапезу роду и роженицам. <..> А вы поете песнь бесовскую идолу роду и роженицам. <..> Се же слышавше, останите, братие, того пустошнаго тварения и службы сотонины и ставлениа трапезы кумирьскыя роду и роженицем» (Гальковский 2013: 350-353).

Кроме того, следует учесть, что для древнерусских книжников был характерен недифференцированный подход к дохристианским 
верованиям в принципе: все они рассматривались как «эллинство», вне зависимости от их происхождения. В «Слове об идолах», составленном древнерусским автором на основе сочинения Григория Богослова (IV век) против языческих обрядов, почитание рода и рожаниц упоминается в широком контексте восточных и античных языческих верований: «Проклятаго же Осирида рожен, мати бо его ражающи, и того створиша богом собе, и требы ему силны творяху окаинии. От тех извыкоша халдеи начаша требы им творити великия, роду и роженицам, пороженью проклятаго бога их Осира. <...> Откуду же извыкоша елени класти требы Артемиду и Артемиде, рекше роду и роженице. Тиции же игуптяне. Тако же и до словен доиде. <..> И те начаша требы класти роду и рожаницам преже Перуна, бога их, а переже того клали требу упирем и берегиням. По святем же крещеньи Перуна отринуша, но и ноне по украинам молятся ему проклятому богу Перуну, и Хорсу, и Мокоши, и Вилу, и то творят отаи. Сего не могут ся лишити проклятаго ставленья 2-я тряпезы роду и рожаницам» (Гальковский 2013: 288-289).

Выявить в такого рода источниках указания на обычаи, имевшие исключительно славянское происхождение, довольно сложно, если вообще возможно: дохристианские обряды и верования восточных славян не только не отделялись, но и напрямую возводились к древневосточным и античным религиям. С точки зрения древнерусских обличителей, такой подход был вполне оправдан, ибо опирался на авторитетные образцы, выработанные их раннехристианскими предшественниками, сквозь призму сочинений которых языческое происхождение приписывалось отдельным феноменам древнерусского быта. Последние по своему происхождению далеко не всегда являлись автохтонными, ведь «вместе с христианством Русь получила из Греции немало обычаев, представлений и апокрифов, не укладывающихся в рамки канона» (Петрухин 2000: 327). Некоторые упомянутые книжниками обычаи, вероятно, вообе не существовали на восточнославянской почве, а известия о них отражают не древнерусские реалии, будучи лишь книжными заимствованиями из авторитетных текстов. По замечанию В. Й. Мансикки (2005: 135), свидетельство «Слова Исайи пророка», «где "род" и "роженицы" передают отвлеченное понятие "счастья" и “судьбы”, не дает права решать, существовали ли у славян божества судьбы как самостоятельные демонические существа». Фактически он снимает вопрос о восточнославянской персонификации рожаниц, рассматривая их как литературное заимствование из гре- 
ческой традиции, где эти обличения были актуальны. А неоднократные упоминания о "рожаничном культе» в древнерусских сочинениях против язычества исследователь склонен объяснять характерной для Средневековья инерцией литературной традиции.

Поэтому вполне актуальным представляется вопрос о том, что именно за воззрения скрывались за почитанием рожаниц, которым были посвящены застолья, насколько эти празднества носили ритуальный - языческий или не вполне канонический, но все же христианский по своему происхождению - характер и к каким событиям были приурочены.

Сущность понятия «рожаница» не единожды становилась предметом ученых изысканий. Выдержка из Книги пророка Исайи в составе паремейника 1271 года с упоминанием рожаниц - «Вы же оставльшеи мя, и забывьшеи гору святую мою и готовающеи рожаницям тряпезу, и испольняюще демонови чьрпание - аз предам вы во оружие» - стала основой рассуждений И. И. Срезневского. Обратившись к дословному переводу ветхозаветного отрывка, исследователь обнаружил, что «рожаница» появилась в славянском тексте пророчеств Исайи «как перевод еврейского Гад... греческо-

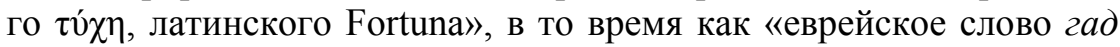
значит счастие». Дальнейший ход рассуждений позволил провести параллели между рожаницей и римской Фортуной, которая «отличаема была от судьбы тем, что понятие о ней соединялось с понятием об изменчивости, непостоянстве, между тем как Судьба представляема была неизменною». Кроме того, он обратил внимание на свидетельство Прокопия Кесарийского о том, что «славяне судьбы ( $\left.\dot{\iota} \mu \alpha \rho \mu \varepsilon^{\prime} \eta v\right)$ не признают, а признают благость и силу Провидения Божия, надеясь молитвой и жертвой испросить себе его милость...

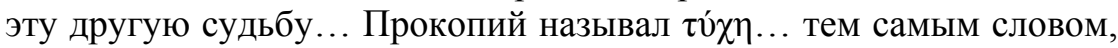
которое позже переводимо было по-славянски Рожденицей». Таким образом, основываясь на параллелях с греко-римской религией, исследователь сделал вывод, что рожаницы представляли собой славянский извод античных мойр (Срезневский 1855: 3, 13-17).

В том же духе высказывался и А. Н. Веселовский, отождествлявший рода древнерусских поучений с домовым, то есть духом умершего предка ${ }^{1}$, а рожаниц, которым «молились, клали требы,

${ }^{1}$ Схожее мнение высказывал и Н. М. Гальковский (2013: 110), полагавший, что «под культом рода и рожаниц разумеется древний культ мертвых, предков, сохранившийся даже и до наших дней». Видел в рожаницах «духов умерших родственниц, собравшихся в дом, где родился новый член рода» и В. Й. Мансикка (2005: 225). 
ставили трапезу... каши, как и греческим мойрам, приходящим одаривать новорожденного долею», полагал девами судьбы (Веселовский 1889: 177-178).

Несколько с иных позиций подошел к проблеме персонификации рожаниц Б. А. Рыбаков. Для него большое значение имело их упоминание в качестве кумиров, то есть языческих богинь. Опираясь на упоминание рожаничных трапез в «Слове Григория об идолах» и свидетельство «Слово некоего христолюбца» о современниках, совмещавших «чистыя молитвы с проклятым молением идольскым, иже ставят лише трапезы кутинныя и законьнаго обеда иже нарицается незаконьная тряпеза и менимая роду и рожаницам в гнев Богу» (Гальковский 2013: 307), исследователь заключил, что «культ рожаниц отличался... своей явностью, открытостью, торжественными пирами в честь богинь, частично замаскированными празднествами Богородицы» (Рыбаков 1981: 466). Такой взгляд на рожаниц вполне соответствовал концепции о двоеверии, в рамках которой «эволюция религиозных представлений являла собой не полную смену одних форм другими, а наслаивание нового на старое» (Там же: 597).

Очевидно, что попытки рассматривать рожаниц как персонифицированных представительниц восточнославянского языческого пантеона основываются главным образом на сопоставлении их с аналогичными, на взгляд исследователей, божествами иных народов. Так, Б. А. Рыбаков (Там же: 465), обосновывая гипотезу о парности рожаниц ${ }^{2}$, взялся «сопоставлять пару славянских богинь с далекими первобытными мифами». По его мнению, древнегреческую аналогию рожаницам составляли две пары женских божеств: Деметра - Персефона и Лето - Артемида. Однако И. И. Срезневский (1855: 21) отмечал, что «роженицы представлялись воображению славян то парами, то триадами», как «парами или триадами представлялись девы жизни у всех их соседей». А. Н. Веселовский (1889: 194), значительно расширивший базу аналогий, настаивал на троичности рожаниц: «...их троичность - излюбленная эпическая подробность». Поэтому не будет преувеличением заключить, что всевозможные сближения рожаниц с женскими божествами иных народов - проблема, разумеется, интересная, но мало что дающая

2 Парность рожаниц Рыбаков (1981: 464-465) обосновывает исходя из употребления слова «рожаницы» в форме двойственного числа в одном из ранних списков «Слова Исайи пророка». Очевидно, судить о том, насколько эта грамматическая форма использовалась целенаправленно, следует с осторожностью. 
для прояснения сущности рожаниц и изменения представлений о них в восточнославянской среде.

Интересно и другое. А. Н. Веселовский (1889: 193-194) в число прототипов рожаниц включил германских норн, которые «являются к новорожденному... нарицают судьбу». Однако в диахронической перспективе «их понимание спустилось к значению вещих жен» и в таком виде сохранилось в эпосе, литературной традиции. Но, как замечает В. Я. Петрухин (2000: 322-323), в восточнославянской среде «никаких реальных фольклорных свидетельств о роде и рожаницах не сохранилось». Поэтому метод аналогий, сопоставления религиозных представлений восточных славян с верованиями иных народов едва ли оправдан, а «род и рожаницы оказываются, прежде всего, глоссами русских книжников, призванными пояснить византийские тексты», на основе которых обличаются пережитки восточнославянского язычества. Разумеется, едва ли рожаниц можно рассматривать как персонифицированных богинь судьбы восточнославянского пантеона, хотя «в древнерусских текстах род и рожаницы - это действительно воплощение судьбы, родословья, того, что на роду написано» (Там же: 318). Разыскания относительно упоминания рода в древнерусском «Слове о вдуновении духа в человека» подтверждают это заключение: род в указанном контексте понимается как судьба, вне олицетворения ее с каким-либо персонажем восточнославянского пантеона (Казаков 2016: 128-133).

Однако утверждение, что использование древнерусскими книжниками понятий «род» и «рожаницы» имело связь исключительно с представлениями о судьбе, не исчерпывает глубины вопроса. Н. И. Зубов (1995: 46), обратившись к «Слову об идолах», отметил, что этому памятнику «соответствует византийский протооригинал, принадлежащий св. Григорию Назианзину (Богослову)», который посвящен «развенчиванию античных культов богиниматери и бога-сына». «Слово об идолах» демонстрирует малопривлекательную картину рождения (Осирис, например, «нелепым проходом проиде рожаяся, того ради и богом его нарекоша») и дальнейшего распространения культов языческих богов. Исследователь вполне справедливо отмечает, что в русле рассуждений Григория Богослова и древнерусского толкователя его сочинения «христианская Богородица и ее сын-Бог должны вытеснить прочих “рожениц” и “родов” с их противоестественными и гадкими обстоятельствами появления на свет». Поэтому «названия род и рожа- 
ница... предстают в том изначальном нарицательном смысле, который, очевидно, и вкладывали в них первые древнерусские составители документа: род - это тот, кто родился; рожаница - это та, которая рожает». Простота и очевидность предложенного Зубовым подхода к определению понятия «рожаницы» в тексте «Слова об идолах» едва ли может быть оспорена. Можно лишь дополнить ее наблюдением, что обличение родов и рожаниц, упомянутых в тексте, лежит в рамках усвоенного древнерусскими книжниками взгляда на почитание языческих богов как твари, вместо творца истинного христианского Бога. Такой подход предполагает, «что происхождение язычества... может и не быть сверхъестественным. Даже напротив» (Аничков 2009: 160). Подробности о «рождении» тех или иных языческих богов и их матерях только подтверждают тот факт, что древнерусский составитель «Слова об идолах» придерживался взгляда на языческих богов как на тварь, именно поэтому поклонение роду и рожаницам было приписано всем языческим народам.

Вместе с тем предположение Н. И. Зубова, что текст «Слова об идолах» «лег в основу всей “антирожаничной” серии» в древнерусской письменности, то есть понимание рода и рожаниц как рождавшихся языческих богов и их родительниц было характерно для всех восточнославянских обличителей в целом, все же сомнительно. Не в его пользу свидетельствуют приведенные выше мнения, раскрывающие связи рода и рожаниц с представлениями о судьбе.

Рассмотренные до сих пор мнения ученых основываются преимущественно на текстах обличительных, которые, разумеется, улавливали кое-что из повседневного обихода Древней Руси. Но сам характер памятников, авторы которых стремились в первую очередь установить связь отдельных явлений быта восточных славян со свидетельствами христианских апологетов о феноменах позднеантичного язычества, нимало не раскрывает исходного существа обличаемых обычаев. В этой связи есть смысл обратиться к источникам, касающимся практических вопросов церковной дисциплины. Для такого рода источников характерно более внимательное отношение к повседневным практикам, обычаям и быту в целом. В этой связи примечательна попытка Е. Б. Грузновой подойти к интерпретации существа рожаниц на основе свидетельства одного из таких памятников, упоминающего интересную бытовую деталь: «...бабы каши варят на собрание рожаницам». Исследовательница высказывает мысль, что «на Руси “собрание рожаницам" 
представляло собой совместную трапезу способных к продолжению рода женщин - ведь все они в прошлом, настоящем или будущем являлись роженицами». Вместе с тем, пытаясь объяснить факт обличений подобных собраний христианскими книжниками, исследовательница предполагает, что факт отождествления рожаниц с обычными женщинами «не отменяет реальности существования их культа», который базировался на «языческом миропонимании» (Грузнова 2013: 100, 104).

Не беремся судить, что представляло собой «языческое миропонимание» в Древней Руси, однако отметим, что отождествление рожаниц с родильницами подтверждается известиями из «Вопрошания Кирика» - памятника XII века, касающегося практических моментов христианской дисциплины. «Ответственное положение духовного отца, - указывал С. И. Смирнов (1913: 109 первой пагинации), - обязывало Кирика интересоваться вопросами канонического порядка и считаться с нравами и бытом общества». А Срезневский (1855: 13) обратил внимание, что «у Кирика некоторые комментаторы, без пособия других данных, позволяли себе думать, что под словом Род можно понимать роды, рождение, а под именем Рожениць родильницу». В тексте памятника священноинок Кирик упоминает современников, которые «роду и рожденици крают хлебы и сыры и мед» и получает от архиепископа наставление предостерегать от совершения подобных обрядов: «горе пиющим рожденицам» (Смирнов 1913: 10 второй пагинации). В этом случае велика вероятность, что рожаничная трапеза совершалась в честь женщин, разрешившихся от бремени, и приурочивалась к появлению на свет младенцев.

В пользу этой точки зрения свидетельствует статья учительного характера одного древнерусского сборника XV века: «Се буди ведомо, яко Нестории иеретик научи тряпезу ставити рожаничную мьна Богородицю человекородицю. Святии же отци Лаодикийского сбора слышавше о ангела, зане Богу нелюботворимое то и святеи Богородици, писанием повелеша не творити того. Да кто послушает заповедии святых отец, спасен будет, аще ли кто не послушает, отлучен да будет» (Гальковский 2013: 113). Автор ополчается на связанное, по-видимому, с праздником Рождества Христова поставление рожаничной трапезы в честь Богородицы. Феномен рожаничной трапезы в данном случае был осмыслен обличителем на основе обращения к авторитетным каноническим текстам, однако найденное сходство едва ли свидетельствовало о том, что участни- 
ки действа сознательно следовали учению Нестория. Интересно другое: поставление трапезы в честь Богородицы рассматривается как признак того, что рожденный ею младенец был простым человеком. Вероятно, для обличителя рожаничная трапеза, приуроченная к разрешению его современниц от бремени, представляла обычное явление, он протестовал исключительно против приравнивания к обычным женщинам Девы Марии, родившей младенца, соединявшего человеческую природу с божественной.

Итак, скорее всего, рожаничная трапеза была связана с появлением на свет ребенка и поставлялась в честь новоявленной родильницы. Более внимательное рассмотрение как древнерусской родильной обрядности, так и отношения к ней церкви позволяет прояснить вопрос о том, почему рожаничные трапезы вызывали столь негативную реакцию книжников. «Вопрошание Кирика» дает ясное представление, каково было отношение церкви к родам: «А се подобает ведати, в нем же храме дитя мати родит, не достоит влазити во нь. Помьют вы всю и молитву створят над суном осквернившемся, а добрее было до осьмаго дне. Аще ли кто влазит во храмину ту, да не входят в церковь по 3 дни, потом измыется взем молитву чистую и тако влазит во церковь» (Смирнов 1913: 8 второй пагинации). С. И. Смирнов (Там же: 119 первой пагинации), комментируя эту статью, справедливо отмечал, что «рождение ребенка рассматривалось как явление, оскверняющее не только мать, но даже и ту храмину, где оно произошло, обитателей этого дома и особенно повивальную бабку. В дом, где родился ребенок, можно было входить не ранее, как через три дня, предварительно весь вымыв и прочитав молитву, которую творят над оскверненным сосудом».

Примечательно, что на Руси традиционным местом родов были бани. Новгородский архиепископ Илия (1165-1186) в поучении к духовенству упоминает «о крещеньи детинем» и рекомендует попам «в перьвый день» по рождении младенца, «егда зовут вы к перьти, творите молитву, юже творят над [со]судом оскверньшимся». «Перьть», упомянутая владыкой, есть не что иное, как баня; поэтому свидетельства Илии вполне «указывают на существование в Новгороде уже в XII веке обычая отводить беременную женщину для разрешения от бремени в баню» (Павлов 1890: 291).

Баня была откровенно опасным и нечистым местом, связанным с проявлением враждебных человеку духов, там «жил особый дух банник... поэтому в баню не следовало ходить в одиночку» (Райан 
2006: 89). Последнее нередко связывалось с дохристианскими воззрениями восточных славян, сохранившимися и в христианскую эпоху: так, Б. А. Успенский (1982: 154) полагает, «что великорусская баня... представляла собой домашний храм Волосу». Едва ли это так, во всяком случае, по замечанию В. Ф. Райана (2006: 90), «демонические обитатели русской бани имеют четкие соответствия в раннем христианстве», откуда, вероятно, на Русь и пришло представление о сугубой нечистоте бани ${ }^{3}$, которое удачно сопрягалось с представлением о нечистоте родов в целом и родильницы в частности. Не исключено, что представление о нечистоте родов в восточнославянской среде также формировалось в результате христианизации. Правда, как полагает В. Я. Петрухин (2000: 334-335), основанное на ветхозаветных установлениях отношение церкви к нечистоте всего, связанного с родами, совпадает с исконными взглядами славян. Даже если это так, очевидно, что распространение христианства на Руси лишь укрепило подобные представления. Кстати, в католическом мире эпохи Средневековья обнаруживается та же тенденция: по свидетельству А. Я. Гуревича (2007: 476), «родившая женщина считалась нечистой, и рядом церковных предписаний... ей возбранялось в течение определенного (часто сорокадневного) срока входить во храм Божий. Эти ограничения проистекали из ветхозаветных запретов».

Поскольку роды были отнесены церковью к явлениям нечистым и даже способным осквернить не только саму родильницу и младенца, но и окружающих, очевидно, что в этом случае под подозрение попадала вся родильная обрядность в целом, вне зависимости от того, была ли она автохтонной или испытала на себе влияние апокрифических греческих образцов. О последних свидетельствует получивший распространение на Руси культ Соломониды повивальной бабки Христа. В родильной обрядности Средневековья, очевидно, исключительной была роль повитухи, которая, если исходить из церковных представлений, являлась существом сугубо нечистым. Деятельности повитух посвящена и одна из ста-

${ }^{3}$ В. Ф. Райан (2006: 373), критикуя характерную для Б. А. Успенского тенденцию «показать сохранение культа славянского бога Волоса (Велеса)» в христианизированной восточнославянской среде, отмечает, что «подобная интерпретация вызывает вопросы в тех случаях, когда русские верования и практики имеют аналогии в культурах, не знакомых... с Волосом». Стремление оценивать феномены народных религиозных представлений как проявления «язычества», основанное лишь на суждениях исследователя о должном и допустимом в рамках христианского мировоззрения, в целом характерно для отечественных разработок по данной проблематике. 


\section{2 Историческая психология и социология истории 1/2018}

тей «Вопрошания Кирика»: «Аще то бабят, а тем повеле на 15 лет отлучитись от церкви, и взем молитва чистаа, то ж влазит» (Смирнов 1913: 10 второй пагинации). «Бабить» в данном случае означает «быть повивальной бабкой» (Срезневский 2003, т. 1: 37), деятельность которой, как видно из приведенной статьи, подвергалась суровому дисциплинарному взысканию: она попросту не допускалась в церковь. Тем самым повитухи вытеснялись на периферию христианизированного пространства древнерусской повседневности. К тому же Средневековье было временем, «когда трудно говорить даже о рудиментарной медицине», именно поэтому «наряду с естественноприродными способами лечения и знахарством (впрочем, едва ли различимыми) огромную роль должны были играть всякого рода заклинания» (Гуревич 2007: 477). В древнерусском языке понятие «баба», которое применялось к повитухе, имело еще одно значение - «ворожея» (Срезневский 2003, т. 1: 35-37). Поэтому, очевидно, ее деятельность при родах была связана не только с «врачебной», но и с магической помощью. Такого рода практики хорошо описываются следующим, правда, довольно поздним, XVIII века, свидетельством: «Волсви и еретицы и богомерские бабы-кудесницы и иная множайшая волшебствуют и березки подвязывают и ветвие сплетают, жив будет человек того лета, и богатки и смолянки и вербу в стену вторгнет, да не умрет того лета, и с робят первые волосы стригут, а бабы каши варят на собрание рожаницам» (цит. по: Смирнов 1909: 229). Внешне может показаться, что «эти бабы богомерзкие - хранительницы языческих преданий и волшебной мудрости были крайне вредны: отступницы христианства, они увлекали к отступничеству нетвердых верою христиан русских» (Там же: 234).

В действительности, однако, дело обстояло куда сложнее. Родильная обрядность, да и магические практики вообще, постепенно испытывала влияние христианской культуры, зачастую, правда, не всегда каноничного свойства: выше упоминалось о распространении культа апокрифической Соломониды, «бабившей» самого Христа. Этот не признанный церковью культ принимал весьма специфические формы: существовали соответствующие заговоры, призывавшие ее имя, а траву, известную как соломонидина ручка, «использовали знахари для лечения импотенции, женских болезней, болей в груди и грыжи у детей» (Райан 2006: 263, 398).

Очевидно, определенную роль в христианизации родильной обрядности играло приходское духовенство. В одном из списков 
«Слова об идолах» упоминаются «череву работни попове», которые «уставиша трепарь прикладати Рожства Богородици к рожаничной тряпезе отклады деюче» (Гальковский 2013: 289), а соответствующая дисциплинарная статья грозила за такое поведение суровыми прещениями: «Аще кто крестит вторую трапезу роду и роженицам трепарем святыя Богородица, и тои яст и пиет, да будет проклят» (Смирнов 1913: 126 второй пагинации). В ученых трудах высказывалось мнение, что представители духовенства не видели ничего зазорного в своем участии в рожаничных трапезах исключительно потому, что этот обычай был заимствованным, пришел на Русь вместе с христианством, будучи «пережитком древнехристианского обычая приносить хлебы для евхаристии - для обряда требовался лишь один хлеб, прочие употреблялись для трапезы» (Петрухин 2000: 323 и след.).

Но тогда приходится согласиться с точкой зрения, что рожаничные трапезы были приурочены исключительно к церковным праздникам. Сторонником этой гипотезы был Б. А. Рыбаков (1981: 408-409), относивший рожаничные трапезы к 9 сентября, следующему за праздником Рождества Богородицы дню ${ }^{4},-$ именно поэтому, по его мнению, попы «прикладывали» соответствующий тропарь. Само же действо представлялось исследователю «общественным осенним праздником урожая», недаром ведь он видел аналогии восточнославянских рожаниц в античных богинях плодородия Деметре и Персефоне. Н. И. Зубов (1995: 46) полагает, что «Род календарно был приурочен ко второму дню рождественских праздников - так называемому собору или “пологу" Богородицы. К 9 сентября... была приурочена так называемая вторая рожаничная трапеза, с празднованием которой активно боролась церковь». В. Я. Петрухин (2000: 323-324) считает, что эти празднества могли быть приурочены к Рождеству Христову и Успению Богородицы соответственно. Е. Б. Грузнова (2013: 100) пришла к выводу, что рожаничная трапеза «могла быть двух видов - по поводу завершения обычных родов и в связи с празднованием рождения Христа».

Очевидно, что на эти выводы повлияло заключение А. Н. Веселовского (1889: 178-179) о возможном отождествлении в народном сознании рожаницы с Богородицей, а рода - с Рождеством. Сыграло свою роль и упоминание в источниках пения тропаря Рождества

${ }^{4}$ Следует отметить, что 9 сентября по церковному календарю совершается память родителей Богородицы, праведных Иоакима и Анны. По народным поверьям, этот день весьма благоприятен для родов (Райан 2006: 88). 
Богородицы во время рожаничных трапез, которые ставились «лише тряпезы кутинныя и законьнаго обеда» (Гальковский 2013: 307). «Законный обед, - пишет В. Я. Петрухин (2000: 325), - видимо, трапеза в честь Богородицы, “беззаконная трапеза” - та “вторая трапеза", от участия в которой не могли отказать себе попы “череву работни" (чревоугодники)».

Впрочем, упоминание «ставленья 2-я тряпезы нареченыя роду и рожаницам» есть смысл привязать не только к великим христианским праздникам. В пользу этого может свидетельствовать послание киевского митрополита Михаила (1590 год) о народном праздновании в честь Богородицы: из послания следует, что среди паствы «обретеся некая соблазна», состоящая в том, что «назавтрие Рожества Христова носят пирогы, мнят в честь Богородицы полог навежаючи, еже есть великое нечестие и наука нечестивых еретик: Дева же Богородица, паче слова и разума, нетленно и несказано роди» (Гальковский 2013: 114). Это послание имеет много общего с упомянутой выше статьей, в которой возникновение рожаничных трапез связывается с инициативой еретика Нестория; оба эти памятника якобы отражали процесс «смешения Богородицы с рожаницей» в народном сознании (Там же: 115).

Однако можно предложить и иной взгляд на приведенный отрывок и разъяснить, почему рожаничную трапезу называли второй: возможно, она совершалась «назавтрие», то есть на второй день после родов. Точка зрения, что эта трапеза «устраивается... после церковного празднования, сверх разрешенного церковью пированья» (Рыбаков 1981: 468), спекулятивна. Она зиждется на интерпретации выдержки из «Слова христолюбца», что рожаничную трапезу «ставять лише тряпезы кутинныя и законьнаго обеда». Сама фраза отнюдь не свидетельствует, что «незаконьная тряпеза» устраивалась после благословляемого церковью обеда: в данном случае предлог «лише» употреблен в значении «кроме», «помимо» (Срезневский 2003, т. 2: 35), а никак не в значении «после», как предлагает Рыбаков. Упоминание «законьнаго обеда» может не указывать на последовательность трапез, а употребляться ради противопоставления рожаничной трапезе, совершаемой «в гнев Богу», в качестве ее антипода.

Интересно и другое. Если рожаничная трапеза в честь родильницы и новорожденного совершалась уже на второй день после родов, то, очевидно, она никак не могла быть одобряема церковью, которая, как следует из «Вопрошания Кирика», во избежание 
осквернения рекомендовала воздержаться от общения с родильницей «до осмаго дне». Не будет преувеличением предположить, что такое почитание родильницы восходило к дохристианским временам, хотя, быть может, и не содержало каких-то явных языческих черт, к тому же этот обычай явно трансформировался со временем. Тем не менее рожаничные трапезы нарушали церковную дисциплину, именно поэтому они были отнесены к проявлениям «чужой веры», нехристианского нечестия. Здесь стоит согласиться с В. Я. Петрухиным (2000: 338), что «народные обычаи для церкви “поганские" и даже не собственно “народные", ибо “новый” народ - народ христианский, а чужие».

Однако говорить о том, что обычаи, подобные рожаничным трапезам, были двоеверными, едва ли правильно. Понятие о двоеверии как о механическом встраивании христианских элементов в панораму языческих представлений, когда «сознание оставалось языческим по самой своей сути», а христианство «рассматривалось им через призму представлений и так или иначе включалось в существующую картину мира» (Грузнова 2013: 6), является не только упрощением, но и прямым искажением действительности.

В этой связи уместно обратиться к наработкам В. М. Живова (2002), отмечавшего, что двоеверное смешение христианских и языческих черт в повседневных практиках возможно «лишь в том случае, если имеет место осознанная оппозиция двух ценностных полюсов и вместе с тем отсутствует переходная зона совмещения христианского и языческого поведения». Вместе с тем рожаничные трапезы могут быть отнесены как раз к «переходной зоне», в которой взаимодействуют христианские и языческие элементы. Участие в рожаничных трапезах попа, стремившегося внести в действо христианский смысл, пусть даже и в нарушение церковной дисциплины, и бабы-повитухи, персонажа с точки зрения христианского благочестия весьма подозрительного, снимает поляризованность христианских и языческих элементов. Последние в этом случае оказываются своего рода «слабым звеном», поскольку язычество само по себе не образовывало сколько-нибудь целостной системы, не очерчивало четких границ, отделяющих его от христианства и других религий, а, наоборот, обладало способностью вбирать в себя элементы различного происхождения (Казаков 2016). Происходит десемантизация, «утрата тем или иным элементом синхронной связи с системой антиповедения», к которой обличители относили действа, подобные рожаничным трапезам. Элемен- 
ты, утратившие связь со своим исконным смысловым наполнением, едва ли можно назвать собственно языческими, хотя они, очевидно, демонстрируют исключительную живучесть, а их «языческое начало» вычленяется лишь церковными ригористами. Последние опирались на совершенно не связанные с порицаемыми практиками образцы раннехристианского происхождения; именно поэтому рожаницы могли быть обличаемы и как «кумиры», и как представления о судьбе. При этом «религиозный ригоризм, акцентирующий нечистое происхождение народных обычаев, как раз и был обусловлен тем, что общераспространенным было восприятие их как нейтральных элементов, не противоречащих христианству» (Живов 2002: 308-311).

О постепенной утрате связей рожаничных трапез с дохристианскими воззрениями свидетельствует факт поставления их в честь Богородицы, совершаемого на второй день Рождества Христова. Вопреки ученой традиции, видевшей в этом обычае доказательство переноса функций языческой рожаницы на Богородицу, следует отметить, что такого рода перемена как раз была признаком довольно глубокой христианизации народной среды. Почитание Богородицы столь прочно вошло в повседневный обиход, ее образ стал столь близок и понятен, что факт рождения ею Христа максимально сближался с родами обычных женщин, а распространение апокрифов о повитухе Соломониде только способствовало этому сближению.

В целом отношение к рожаничным трапезам, очевидно, менялось с распространением христианства вширь и вглубь: не исключено, что со временем усилия благословлявших празднества попов привели к переменам в восприятии этого феномена. А. Я. Гуревич (2007: 476) писал о постепенной эволюции взглядов относительно нечистоты родов в западном христианстве. Их сменяло представление, что «на роженице не лежит субъективной вины, которая могла бы послужить препятствием к принятию таинств, и древнеиудейский запрет утратил силу; греховно вожделение, но не роды. Поэтому даже в тот самый день, когда она разрешилась от бремени, женщина вправе вступить в дом Господа, дабы вознести Ему благодарственную молитву». Этот взгляд был официально утвержден Римской церковью в 1140 году, однако еще в XIII - начале XIV века многие представители католического духовенства держались старых представлений. 
Ситуация на Руси развивалась иным путем. С одной стороны, в XVII веке сохранялся обычай родов в бане, причем не только в крестьянской среде, но и среди представительниц высших слоев общества: во времена Алексея Михайловича «с приближением родов даже царица отправлялась в баню, куда ее сопровождала повитуха и ближайшие прислужницы, остававшиеся с ней до момента рождения младенца» (Райан 2006: 91). С другой стороны, регулирующие церковную дисциплину установления обнаруживают большую терпимость к родильницам, в частности, к XVI веку появляется правило, фактически дозволяющее рожаничные трапезы, правда, с единственным условием: «Жена аще родит дитя, то, молитву взем, тоже ясти с нею, аще не взем молитвы, то ни» (Смирнов 1913: 119 первой пагинации). Христианизация, вероятно, не обошла стороной даже деятельность повитух. Пример тому может являть «старообрядческий беспоповский толк, известный под названием “Бабушкино согласие”, где младенцев крестят именно повивальные бабки» (Успенский 1982: 104). Несмотря на то, что обрядность беспоповцев на момент ее формирования являла образцы беспрецедентного новаторства, все же сложно предположить, что весьма важный обряд крещения мог быть доверен лицу, являющемуся носителем каких-либо языческих пережитков.

Таким образом, рассмотрение феномена рожаничных трапез, несмотря на его обличения книжниками в качестве укорененного в язычестве, парадоксальным образом раскрывает особенности распространения христианства в Древней Руси, причем на уровне бытовых практик.

\section{Лuтература}

Аничков, Е. В. 2009. Язычество и Древняя Русь. М.: Академический проект.

Веселовский, А. Н. 1889. Разыскания в области русского духовного стиха. Вып. 5. Ч. XI-XVII. СПб.: Тип. Академии наук.

Гальковский, Н. М. 2013. Борьба христианства с остатками язычества в Древней Руси. М.: Академический проект.

Грузнова, Е. Б. 2013. На распутье Средневековья: Языческие традиции в русском простонародном быту. СПб.: Изд-во Петербургского ун-та.

Гуревич, А. Я. 2007. Средневековый мир: Культура безмолвствующего большинства. В: Гуревич, А. Я., Избранные труды: Средневековый мир. СПб.: Изд-во Петербургского ун-та. 
Живов, В. М. 2002. Двоеверие и особый характер русской культурной истории. В: Живов, В. М., Разыскания в области истории и предыстории русской культуры. М.: Языки славянской культуры, с. 306-316.

Зубов, Н. И. 1995. Научные фантомы славянского Олимпа. Живая старина 3(7): 46-48.

Казаков, А. А. 2016. Феномен родопочитания в воззрениях книжников Древней Руси: некоторые особенности восприятия. Историческая психология и сочиология истории 2: 121-137.

Мансикка, В. Й. 2005. Религия восточных славян. М.: ИМЛИ РАН.

Павлов, А. С. 1890. Неизданный памятник русского церковного права XII века. Журнал Министерства народного просвещения CCLXXI: $275-300$.

Петрухин, В. Я. 2000. «Боги и бесы» русского Средневековья: род, рожаницы и проблема древнерусского двоеверия. Славянский и балканский фольклор: Народная демонология. М.: Индрик, с. 314-343.

Райан, В. Ф. 2006. Баня в полночь: Исторический обзор магии и гаданий в России. М.: Новое литературное обозрение.

Рыбаков, Б. А. 1981. Язычество древних славян. М.: Наука.

Смирнов, С. И.

1909. «Бабы богомерзкие». В: Барсков, Я. Л., Богоявленский, С. К. и др., Сборник статей, посвященных В. О. Ключевскому. М.: Печатня С. П. Яковлева, с. 217-243.

1913. Древнерусский духовник: Исследования по истории иерковного быта. М.: Синодальная типография.

\section{Срезневский, И. И.}

1855. Роженицы у славян и других народов. М.: Тип. А. Семена.

2003. Материалы для словаря древнерусского языка: в 3 т. Т. I-II. М.: Знак. (Репр. изд. 1893, 1903 г.)

Успенский, Б. А. 1982. Филологические разыскания в области славянских древностей (Реликты язычества в восточнославянском культе Николая Мирликийского). М.: Изд-во Моск. ун-та. 